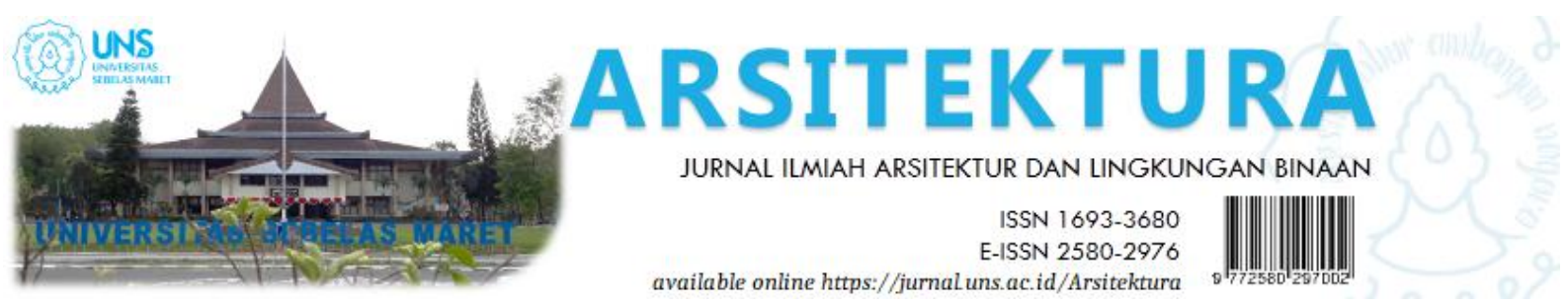

Volume 17 Issue 2 October 2019, pages:185-194

\title{
Pola Permukiman Pesantren Darul 'Ulum Peterongan Jombang Pada Masa Kejayaan Di Tahun 1975
}

\section{Settlement Patterns Pesantren Darul Ulum Peterongan Jombang in The Heyday 1975}

\author{
Jalaluddin Mubarok $^{1 *}$, Titin Woro Murtini ${ }^{2}$, Atik Suprapti ${ }^{3}$ \\ Prodi Magister Arsitektur, Fakultas Teknik Universitas Diponegoro Semarang ${ }^{1 *}$ \\ Email: jalaluddinmubarok18@ @student.undip.ac.id \\ Prodi Magister Arsitektur, Fakultas Teknik Universitas Diponegoro Semarang ${ }^{2}$ \\ Prodi Magister Arsitektur, Fakultas Teknik Universitas Diponegoro Semarang ${ }^{3}$
}

DOI: https://doi.org/10.20961/arst.v17i2.27748

Received: February 8, 2019 Revised: May 10, 2019 Accepted: May 10, 2019 Available online:October 31, 2019

\begin{abstract}
Indonesia is one of the countries with a majority Muslim population. The development of the inhabitants increasingly rapidly due to the development of education. Of the many education in Indonesia, which is the first education in Indonesia was a Pesantren. Pesantren itself is a nonformal institutions developed by one of the Ulama' or people who are experts in the science of Islam. Pesantren is the education which of a teacher and student live together each time, so that they are able to learn the most from life together. The reason this is what makes Islam is becoming increasingly developed with the education and distribution of Ulama' by the Wali Songo. So Indonesia become the country with the development of the world-Islam-an. development of Pesantren itself is from hope, who is in a residential neighborhood. In this study addressed an Islamic education which are in one of the city, with a growing Islamic education, located in Pesantren Darul Ulum Peterongan jombang. One of the developments from this Pesantren is when its Heyday, that in the year 1975. The method of this research is a descriptive qualitative that is describing a condition that exists in the location of the research with an interview to the informant. The results of this research is looking at the development of the existing settlement patterns at Darul Ulum boarding environment Peterongan Jombang.
\end{abstract}

Keywords: pesantren, heyday, pattern

\section{PENDAHULUAN}

Negara Indonesia merupakan Negara dengan kepadatan penduduk Muslim terbesar, yakni lebih dari $87 \%$ memeluk agama Islam, dari total jumlah populasi penduduk 258 juta jiwa. (USCRIF, 2017).

Semakin berkembang pesatnya pesantren di wilayah Jawa, khususnya Jawa Timur. Sekitar 4501 pesantren, mulai dari wilayah Timur
(Madura) hingga Barat (Magetan) dan dari wilayah Utara (Tuban) hingga Selatan (Trenggalek) (Ditpdpontren, Kemenag RI). Dalam catatan BPS Jatim sekitar tahun 2017 mencatat sekitar 55 pondok yang berlokasi di Jombang Jawa Timur dengan jumlah santri sekitar 11.648 ribu santri putra dan 11.087 santri putri. Jumlah ini diambil dari berbagai pondok pesantren yang bernuansa tradisional maupun modern hingga bernuansa campuran 
antara tradisional dan modern, juga ada beberapa pondok yang fokus pada hafalan alQuran dan al-Hadits.

Saat ini jumlah santri yang terdata pada pondok pesantren Darul 'Ulum Peterongan Jombang adalah sekitar 5216 orang. Jumlah ini belum dihitung kembali pada tahun 2018 yang datanya bisa mencapai lebih dari lima ribu santri pada pondok pesantren Darul 'Ulum Peterongan Jombang.

Menurut Herman (2013) Pondok Pesantren adalah pendidikan pertama dan tertua di Indonesia, yang mana keberadaannya mampu mengilhami model dan sistem-sistem yang ditemukan saat ini. Dalam catatan sejarah pondok pesantren dikenal di Indonesia sejak zaman Walisongo Tujuan didirikannya pesantren adalah merupakan lembaga yang awal berdirinya melibatkan peran serta aktif dari masyarakat sekitar, maka tujuan pondok juga tidak lepas dari harapan masyarakat sekitar. (Sukamto, 1999; 41).

Pemukiman merupakan sebuah kawasan permukiman yang ada di dataran bumi yang mana dihuni oleh manusia yang didalamnya meliputi kebutuhan sarana dan prasarana sebagai penunjang kehidupan para pemukim dalam berkehidupan dan penunjang tersebut menjadi kesatuan utuh dengan tempat tinggal yang bersangkutan. (Sumaatmaja, 1998).

Sebelum adanya pesantren yang ada di dusun Pesantren ini. Dalam sejarahnya dahulu terdapat sebuah pohon beringin yang dianggap angker, dan lokasi tersebut dijadikan sebuah tempat markas kejahatan dan digunakan sebagai kegiatan merencanakan tindakan kejahatan, tempat mengumpulkan dan membagi hasil kejahatan. (Sukamto ,1999; 5355). Tidak jauh dari lokasi tersebut juga ada lokalisasi prostitusi. Sehingga biasa dikenal oleh masyarakat Jombang, dusun Pesantren ini adalah termasuk dalam wilayah dengan tingkat kejahatan tinggi atau biasa orang menyebutnya adalah abangan. (Geertz, 1983 dalam Sukamto, 1999)

Pada awal berdirinya pesantren ini yakni pada tahun 1885 yang didirikan oleh Tamim Irsyad ulama' besar asli Madura, santri dari Kyai Kholil Bangkalan, Madura. Saat itu pada awal berdirinya pesantren ini banyak diketemukan berbagai permasalahan diantaranya adalah mulai dari santri yang tidak mampu membayar biaya, boleh tetap masuk dalam dengan membantu pengasuh. Kebutuhan sehari-hari yang semakin meningkat, dan dahulu santri sudah mampu memasak sendiri, sekarang sudah tidak ada lagi, dikarenakan terus muncul dan berkembangnya warung makan, kantin dan sebagainya. Sehingga perkembangannya semakin pesat dalam pembangunan. (Sukamto, 1999).

Setelah mengalami masa-masa sulit tersebut pondok pesantren ini berganti pimpinan pengasuh yang mana masih dari keturunan pendiri pesantren Darul 'Ulum Peterongan Jombang, yakni adalah Kyai Musta'in Romli. Menyebutkan bahwa perkembangan pesantren sudah mulai nampak masa kejayaannya pada masa hampir satu abad ( 1885 - 1985 ). Pada masa ini dinamakan masa kejayaannya dikarenakan perkembangan pendidikan, kepesantren-an, hingga bangunan yang sudah mulai berkembang pesat. (Sukamto, 1999).

Antara manusia dan ruang yang dihuninya memiliki keterikatan yang sangat erat. Maka sebuah permukiman dengan adanya penduduk bisa menjadi implementasi atas sistem kebudayaan dan cara berfikir, kepercayaan, hubungan keluarga, organisasi sosial serta interaksi sosial antar individu dalam suatu masyarakat. Juga mencerminkan status penghuninya. (Rapoport, 1970).

Permukiman terdapat beberapa komponen dan satu dengan yang lainnya saling berhubungan / saling ketergantungan. Komponen tersebut adalah wisma (tempat tinggal), karya (tempat berkarya dan kegiatan usaha), marga (jaringan pergerakan, jaringan jalan dan sarana pengangkutan yang menghubungkan berbagai kegiatan fungsional, suka (tempat rekreasi dan hiburan) dan prasarana (utilitas dan pusat pelayanan kegiatan sosial (Rapoport, 1980).

Ada 5 unsur dalam elemen pembentuk permukiman, yakni isi (contents) dan wadah (container). Contens terdiri dari man, and Society. Sedangkan Container terdiri dari shells, network, and Nature. (Armela et.al., 2015). 
Persebaran adalah menggerombol atau saling menjauhinya antara yang satu dengan yang lain, sedangkan permukiman berasal dari kata housing dalam Bahasa Inggris, yang artinya adalah perumahan dan kata human settlement yang artinya permukiman (Daldjoeni, 1986).

Kondisi fisik lingkungan merupakan faktor penting dalam proses memukimi maupun produk yang berupa permukiman (Bockstael, 1996). Pola persebaran permukiman rural lebih banyak ditemukan oleh faktor fisik lingkungan dibandingkan pertimbangan-pertimbangan sosio-ekonomik semata (Knox, 2004; Hardie, 1997).

Permukiman terencana merupakan suatu area hunian yang dirancang oleh seseorang tokoh. Permukiman ini biasanya berbentuk grid, lingkaran atau poligon dengan sirkulasi jalan berbentuk radial dan berasal dari pusat permukiman. Permukiman tidak terencana berkembang sesuai dengan berjalannya waktu. Permukiman ini biasanya memiliki beberapa keunikan antara lain bentuknya yang tidak beraturan, sirkulasi jalan yang berliku, dan munculnya lorong-lorong di sekitar bangunan (Kostof, 1991:43).

Permukiman terencana adalah permukiman yang pembangunannya terencana secara keseluruhan yang meliputi sarana jalan, drainase, ruang terbuka, pola tata massa, dan lain sebagainya. Permukiman tidak terencana atau permukiman spontan yang dibangun secara bertahap dari unit-unit oleh masingmasing pemilik dengan kondisi lingkungan yang kurang terencana seperti jalan dan drainase. (Sony et.al, 2012).

Ada tiga pola permukiman penduduk dalam hubungannya dengan bentang alamnya, yaitu sebagai berikut:

a. Pola permukiman memanjang (Linear) Pola permukiman memanjang memiliki ciri permukiman berupa deretan memanjang karena mengikuti jalan, sungai, rel kereta api atau pantai.

b. Pola Permukiman Terpusat Pola permukiman ini mengelompok membentuk unit-unit yang kecil dan menyebar, umumnya terdapat di daerah pegunungan atau daerah dataran tinggi yang berelief kasar, dan terkadang daerahnya terisolir. Di daerah pegunungan pola permukiman memusat mengitari mata air dan tanah yang subur. Sedangkan daerah pertambangan di pedalaman permukiman memusat mendekati lokasi pertambangan. Penduduk yang tinggal di permukiman terpusat biasanya masih memiliki hubungan kekerabatan dan hubungan dalam pekerjaan. Pola permukiman ini sengaja dibuat untuk mempermudah komunikasi antar keluarga atau antar teman bekerja.

c. Pola Permukiman Tersebar Pola permukiman tersebar terdapat di daerah dataran tinggi atau daerah gunung api dan daerah-daerah yang kurang subur. Pada daerah ini, penduduk akan mendirikan permukiman secara tersebar karena mencari daerah yang tidak terjal, morfologinya rata dan relatif aman. Mata pencaharian penduduk pada daerah ini sebagian besar dalam bidang pertanian, lading, perkebunan dan peternakan.

Pola Permukiman Islam sebenarnya adalah lingkungan Islam / permukiman Islam dan tradisional memang tidak diterangkan secara jelas pada Al-Qur' an dan Hadits, namun dapat diimplementasikan dalam penjelasan tentang Doktrin terkait tiada Tuhan selain Yang Maha Esa. Sehingga lingkungan adalah kerangka dalam kehidupan manusia untuk bersosialisasi dan beraktifitas. Dengan demikian lingkungan adalah sumber dari kesehatan dan produktifitas dalam mempertahankan kehidupan untuk kemudian menggunakan sumber kebutuhan mereka sehari-hari. (Nangkula, 2015).

Menurut Muhammad Djarot (1986) dalam Suprapti (1997) Permukiman Islam disebut juga sebagai Darussalam. Hal ini diartikan sebagai permukiman yang dapat menimbulkan kesejahteraan dan keselamatan karena rasa patuh para pemukimnya untuk melaksanakan hukum-hukum Islam.

Dalam pemahaman dan penataan tata ruang permukiman yang berada dalam lingkungan pesantren dan permukiman Islam. Hal ini dikaitkan dengan permukiman Islam Jawa kuno atau biasa disebut dengan permukiman Kauman. Pola permukimannya adalah ada beberapa pola yakni; 
a. Pertama adalah konsentrik dengan Masjid sebagai pusat mengekspresikan kedudukan simbolis Masjid sebagai elemen bermakna penting sekaligus sakral. Pola ini sekaligus menyimbolkan orientasi pandangan hidup warga sekitar/warga kampung Islam terhadap Tuhan dan nilai - nilai luhur Islam.

b. Kemudian ada pola linier, pola ini masjid sebagai titik orientasi pergerakan publik melalui koridor jalan utama kampung yang mana mencirikan kekuatan orientasi hidup dan pandangan warga setempat terhadap Islam.

c. Kemudian terdapat pola sporadik, pola ini dibentuk dari hubungan antara fasilitas keagamaan (langgar) yang tersebar di penjuru kampung menyiratkan bagaimana begitu besarnya pengaruh Islam dalam perilaku dan budaya hidup sehari-hari warga kampung. Ketiga pola ini adalah sebagaimana yang ada pada kampung Kauman Semarang. (Depari, 2014).

Sehingga perkembangan sebuah pesantren dalam permukiman bisa dilakukan pada sebuah penelitian yang mana pada perkembangannya sudah memiliki perkembangan yang pesat, sehingga perkembangan pola permukimannya bisa dilihat secara jelas. Sehingga dilakukan sebuah penelitian mengenai pola permukiman pesantren Darul 'Ulum yang mana pada masa kejayaannya yakni pada tahun 1985 .

\section{METODE}

\subsection{RUANG LINGKUP}

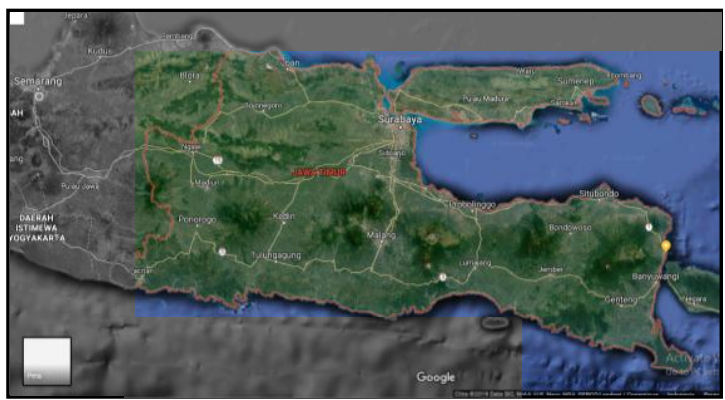

Peta Jawa Timur

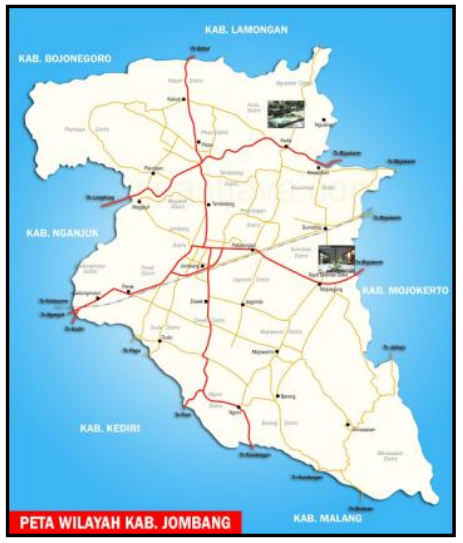

Gambar 1. Peta Jawa Timur dan Kab. Jombang. Sumber: google.co.id diakses 15 September 2018

Lokasi penelitian berada pada wilayah kabupaten Jombang. Kabupaten Jombang adalah sebuah kabupaten yang berada di wilayah Jawa Timur. Wilayah ini termasuk dalam potensi daerah yang maksimal dikarenakan potensi yang berada pada letak geografis yang berada di jalur tengah atau jalur perdagangan. Kabupaten Jombang memiliki luas area 1,159,09 $\mathrm{km}^{2}$ dengan jumlah kepadatan penduduk pada tahun 2014 adalah sekitar 1,236,184 Jiwa.

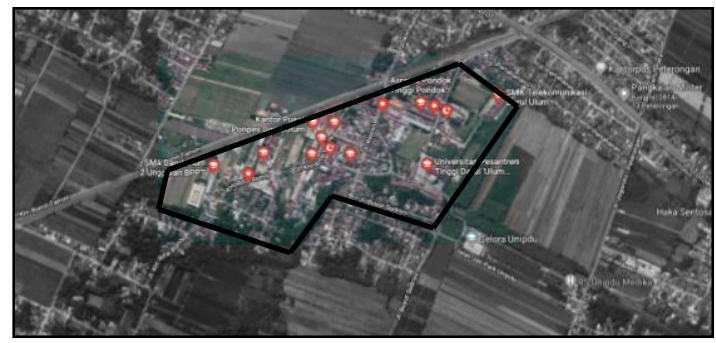

Gambar 2. Peta Lokasi Penelitian di Pesantren Darul 'Ulum Peterongan Jombang.

Sumber: googlemaps.co.id diakses pada 28 September 2018

Lokasi penelitian ini di Dusun Pesantren Kecamatan Peterongan, berada pada wilayah Jombang bagian Tengah yakni memiliki luas sekitar 29,47 $\mathrm{km}^{2}$ dan memiliki kepadatan penduduk 57.350 Jiwa serta terbagi menjadi 14 kecamatan, wilayah ini sangat strategis karena dilalui oleh 2 jalur perdagangan dari jalur Nasional, juga dari jalur perlintasan kereta api, juga terdapat stasiun yang mana mampu menunjang perekonomian masyarakat wilayah ini menjadi lebih cepat berkembang daripada wilayah Jombang yang lainnya. 
Potensi ini banyak dimanfaatkan secara maksimal oleh penduduk wilayah peterongan umumnya dan wilayah Pesantren khususnya, karena stasiun kereta api, dan terminal bayangan terdapat relatif dekat dengan Pesantren ini.

\subsection{METODE PENELITIAN}

Penelitian ini menggunakan metode kualitatif deskriptif, tujuan dari metode penelitian ini adalah menggambarkan, meringkaskan berbagai kondisi, berbagai situasi, atau berbagai fenomena realitas sosial yang ada di masyarakat yang menjadi objek penelitian, dan berupaya menarik realitas itu ke permukaan sebagai suatu ciri, karakter, sifat, model, tanda ataupun gambaran tentang kondisi, situasi, ataupun fenomena tertentu.

Penelitian ini dilakukan dengan cara mendeskripsikan suatu kondisi yang ada dalam pesantren Darul 'Ulum Peterongan Jombang dengan mengkaji pola permukimannya pada masa kejayaannya. Mulai dari menggambarkan latar belakang, permasalahan penelitian, tujuan, tinjauan pustaka, kemudian digambarkan objek penelitian dan penjelasan dari informan, informan tersebut diteliti juga pengumpulan data dan keabsahannya, kemudian dilakukan analisis data dan dilanjutkan membahas objek penelitian dari data informan yang didapat. Setelah dilakukan analisis dan pembahasan, kemudian ditarik kesimpulan dari pembahasan yang telah dilakukan.

\section{HASIL PEMBAHASAN}

Pola permukiman pada zaman kejayaan pesantren Darul 'Ulum Peterongan Jombang adalah ketika zaman dari kepemimpinan Kyai Musta'in Romli. Beliau adalah keturunan dari pendiri pesantren Darul 'Ulum Peterongan Jombang yakni Kyai Irsyad Tamim. Kyai Musta'in Romli memiliki karakter dinamis dan agresif. Hal ini membuat pesantren Darul 'Ulum berkembang menjadi pesantren dengan posisi pendidikan Islam yang berwibawa kembali, setelah sebelumnya mengalami kondisi yang surut. Diantaranya adalah dikarenakan perkembangan pesantren yang kurang memadai dalam hal pengembangan kawasan, juga dikarenakan atas ketidak-ulet-an dari pengasuh sebelum-sebelumnya.

Setelah kepemimpinannya Gus Ta'in (panggilan Kyai Musta'in Romli) beliau mengembangkan pondok pesantren yang berbasis pendidikan umum, beliau mulai mengembangkan pendidikan setingkat Dasar hingga pada perguruan Tinggi sehingga perkembangan dari pesantren lebih signifikan. Dikarenakan pendidikan semakin berkembang, ber-iringan juga atas perkembangan permukiman juga semakin pesat, sehingga penduduk sekitar dan penduduk dari luar pesantren mulai berbondong-bondong pergi ke kawasan pesantren Darul 'Ulum ini. Sehingga lambat laun mengalami kemajuan dan kepadatan penduduk yang tinggi.

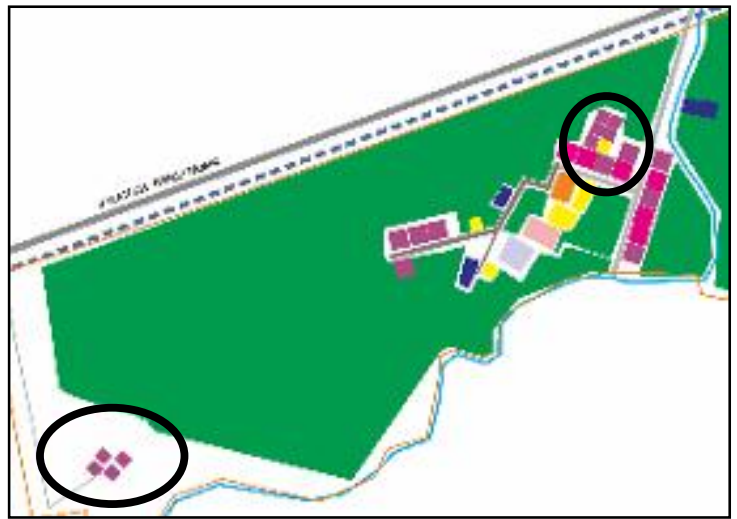

Gambar 3. Perkembangan Permukiman di Pesantren Darul 'Ulum Peterongan Jombang, 1975.

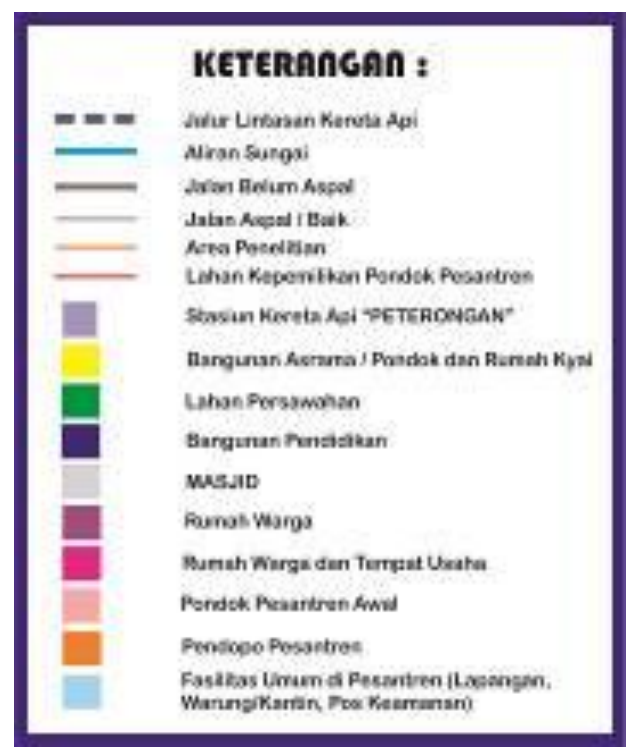

Gambar 4. Keterangan Gambar Kawasan Pesantren. 
Terlihat pada Gambar 3. Perkembangan permukiman pesantren Darul 'Ulum Peterongan Jombang pada masa kejayaannya yang menginjak usia seabad atau sekitar tahun 1975. Permukiman yang terbentuk adalah permukiman yang membentuk sesuai dengan kebutuhan dari penduduk sekitar dan kebutuhan dari pesantren itu sendiri, sehingga pola perkembangan permukimannya adalah tidak terencana, namun sesuai kebutuhan dari masyarakat sekitar maupun masyarakat pendatang.

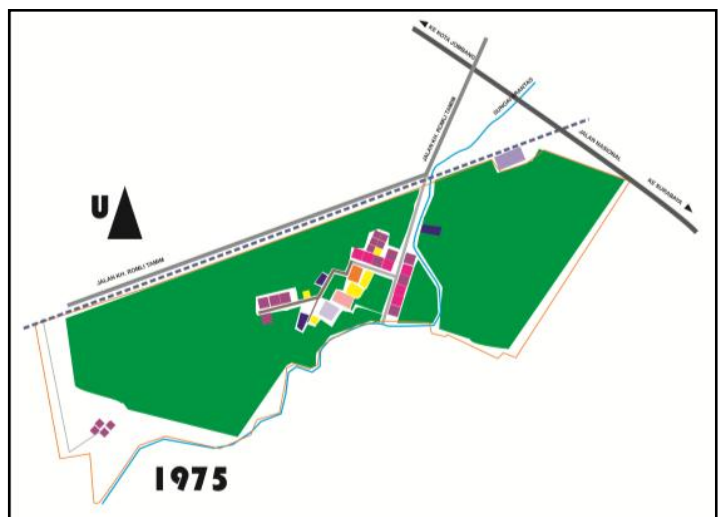

Gambar 5. Peta Lokasi Penelitian di Pesantren Darul 'Ulum Peterongan Jombang, 1975.

Terlihat pada Gambar 5. Bahwa pola permukiman penduduk menjadi padat, yang sebelumnya tidak sebanyak itu. Pola dari perkembangannya adalah sporadik (tersebar) ini dikarenakan pada tiap-tiap persebarannya adalah mengutamakan dari kondisi jalan atau infrastruktur yang sudah terbentuk dari pergerakannya nampak sekali terlihat.

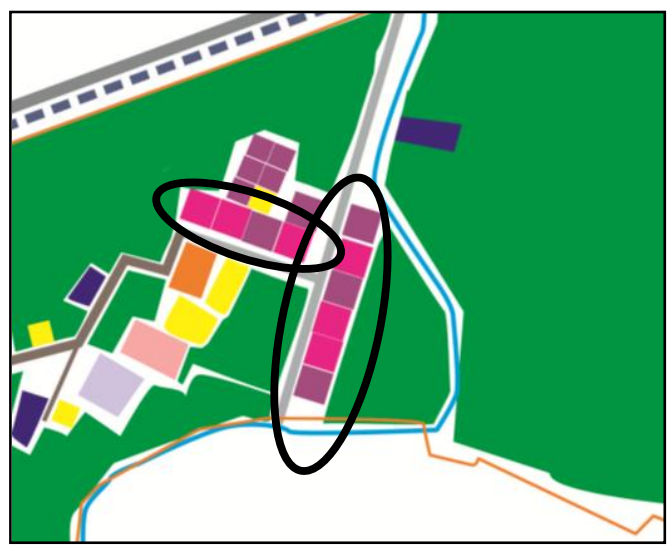

Gambar 6. Perkembangan Tatanan Pola Permukiman di Pesantren Darul 'Ulum Peterongan Jombang, 1975.
Pada Gambar 6. Terlihat pola permukiman yang berkembang pada zaman itu adalah linier, ini dikarenakan posisi jalan dan akses yang membuat permukiman menjadi searah dan linier membuat pola permukiman dari kondisi jalan yang sudah ada. Sehingga persebaran pola permukimannya adalah linier.

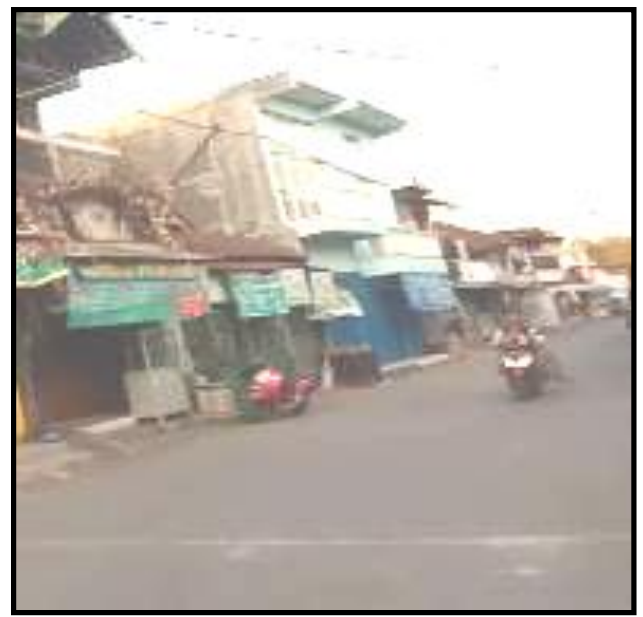

Gambar 7. Permukiman Penduduk.

Salah satu sudut dari permukiman dengan pola linier atau perkembangannya sesuai dengan jalan yang ada, atau akses yang sudah mulai terbentuk. Sehingga pola permukiman yang berkembang pada tahun-tahun tersebut adalah sesuai dengan kondisi jalan, dengan bentuk yang linier juga.

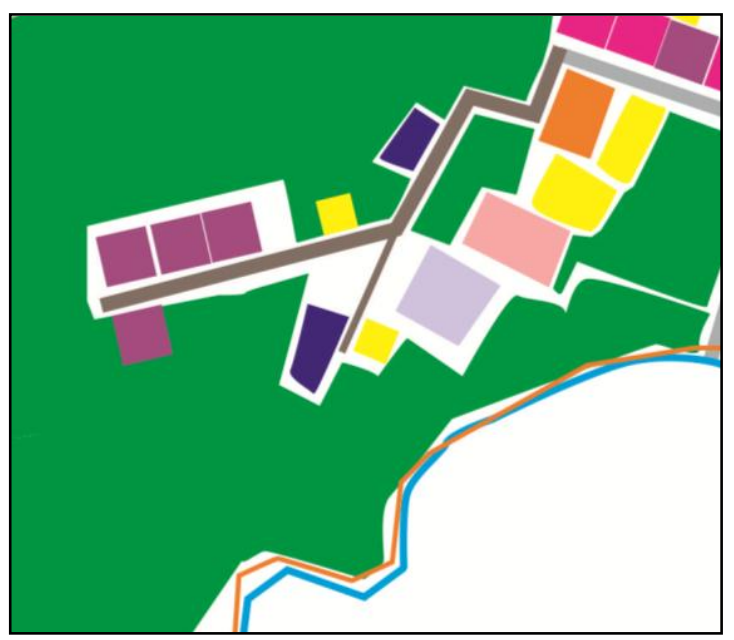

Gambar 8. Pola memusat pada satu titik. 
Pada Gambar 8. Nampak perkembangan pola dari bangunan dan tatanan masanya adalah memusat dikarenakan memusat pada satu sumbu yakni pada Masjid yang sejak tahun sekitar 1880an dibangun, membuat perkembangan pesantrennya baik dari perkembangan tempat tinggal santri, hingga pada pendidikannya memusat pada satu titik yakni masjid.

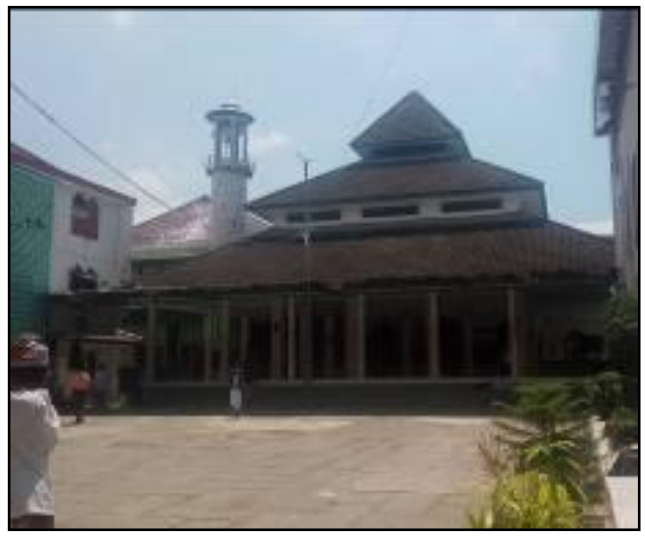

Gambar 9. Masjid Pesantren.

Masjid ini menjadi pusat dari satu titik untuk dijadikan sebagai pusat dari perkembangan suatu kawasan permukiman, mereka menerapkan dari pola permukiman yang menggunakan pola memusat pada satu titik yakni masjid. Sehingga mereka mampu memperoleh kebutuhan secara fisik dan non fisik dari perkembangan kawasan permukiman tersebut.

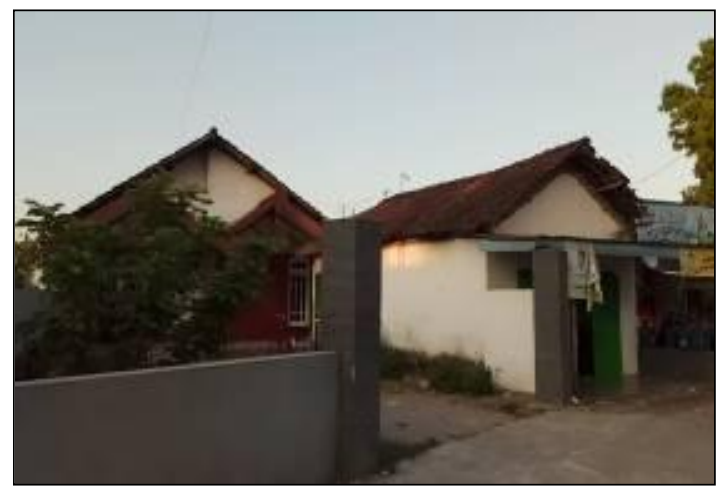

Gambar 10. Permukiman Penduduk.

Pada gambar 10. Sebuah contoh dari kawasan permukiman penduduk yang mana kawasan ini memusat dari ujung jalan ke dalam ujung atau pusat dari masjid. Mereka mengembangkan kawasan ini dari tahun - tahun 1890an hingga tahun 1975 ketika masa kejayaan dari Pesantren Darul 'Ulum Peterongan Jombang.
Hal ini secara tidak langsung mampu menimbulkan dari kawasan permukiman Islam utamanya menjadi kawasan yang dapat menimbulkan orang yang menghuninya menjadi terbantukan secara kesejahteraan dan keselamatan. Dikarenakan mereka secara tidak langsung memiliki rasa patuh untuk menjalankan syariat-syariat atau hukumhukum Islam. (Suprapti, 1997).

Permukiman ini juga tidak terlepas dari faktor penting dalam bermukim, yakni persebarannya secara rural, mereka lebih mengembangkan hunian mereka pada kondisi-kondisi fisik lingkungan daripada kondisi sosio ekonomik saja. (Knox, 2004)

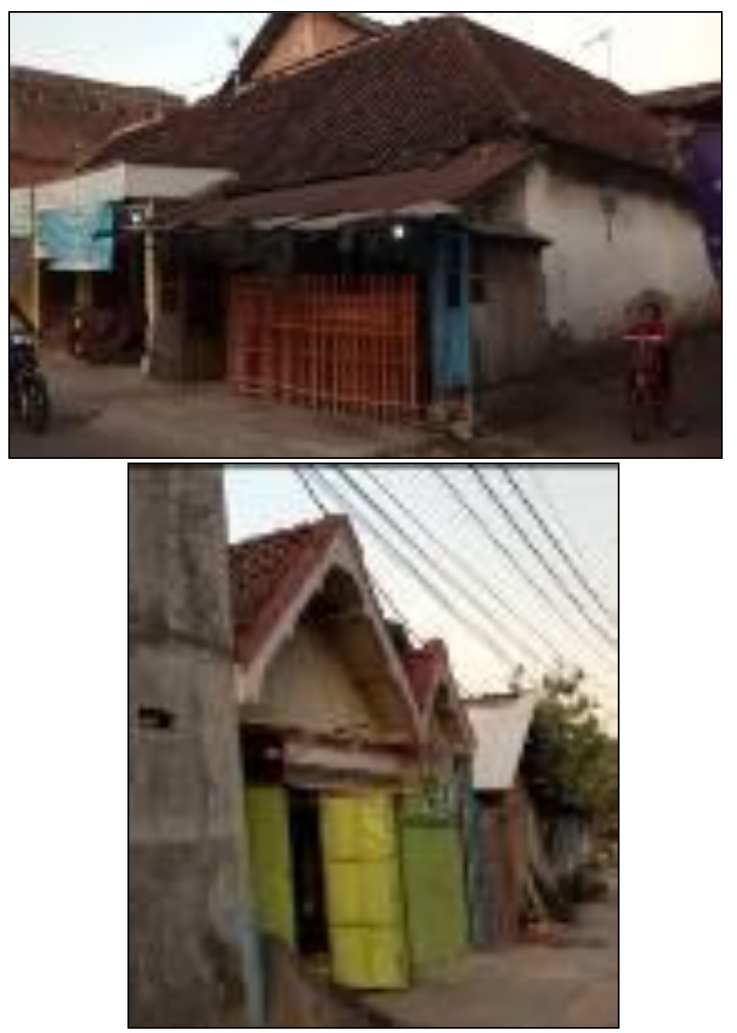

Gambar 11. Permukiman Penduduk.

Salah satu kondisi dari hunian mereka yang memanfaatkan dari kondisi fisik berupa kondisi yang mana berkembangnya adalah secara memusat pada satu titik yaitu masjid. Hal ini juga berpengaruh terhadap kebutuhan dan kemanfaatan yang mereka rasakan daripada hanya sekedar dari kondisi sosioekonomik semata. 


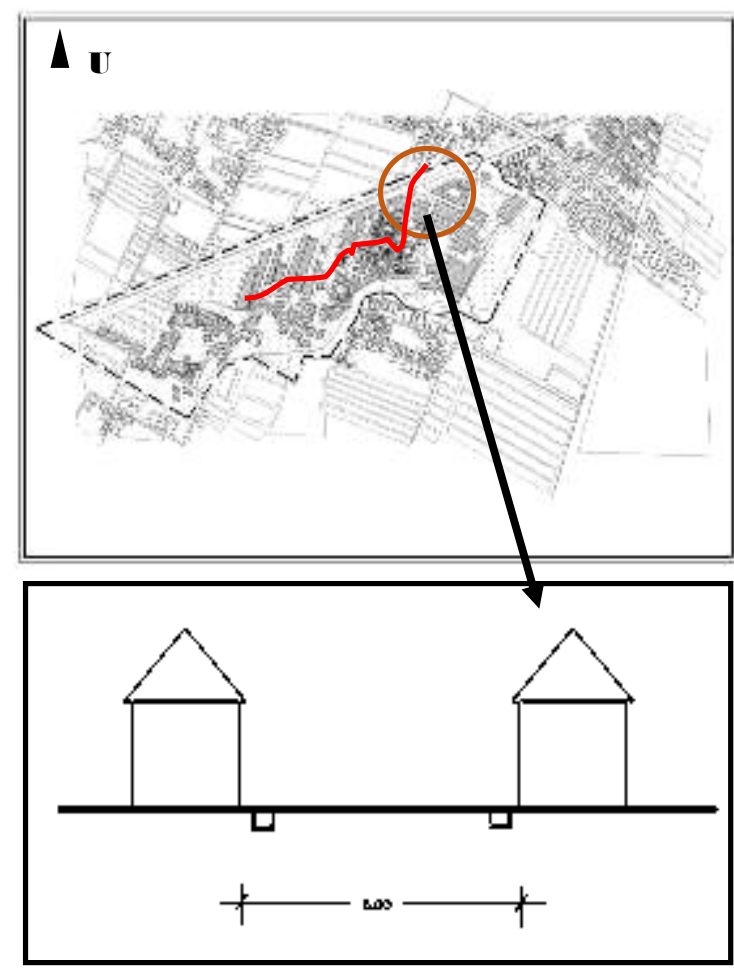

Gambar 12. Ilustrasi Potongan Jaringan Jalan pada Permukiman di Pesantren Darul 'Ulum Peterongan Jombang, 1975.

Perkembangan jaringan jalan dilihat dari tahun 1975 pada masa kejayaan. Bahwa jaringan jalan yang awalnya adalah dari satu akses saja baik masuk maupun keluar. Pada perkembangan zaman, pesantren yang menjadi suatu pendidikan dan kawasan yang diutamakan oleh pemerintah daerah setempat untuk digunakan sebagai area yang dikembangkan dan dilestarikan.

Hal ini membuat pesantren dikembangkan jaringan jalannya, sehingga jaringan jalannya memiliki dua akses masuk dan satu akses keluar yang berbeda, dengan dimensi pada masing - masing jaringan jalannya sekitar 5-6 meter. Sehingga mampu untuk lalu lintas yang lancar dan baik. Seperti pada gambar berikut.

Sehingga pada perkembangan ini membuat pesantren secara umum menjadi lebih teratur berupa jaringan jalan yang dikembangkan, sedangkan permukiman mendapatkan keuntungan berupa jaringan jalan yang lebih baik dan teratur.

Adanya perkembangan jaringan jalan yang ada membuat perkembangan dari pola permukiman menjadi lebih berkembang pesat dan semakin tinggi. Sehingga membuat perkembangan permukiman dari semula hanya linier, berubah menjadi rural, dan sesuai dengan pola pikir dan pola permukiman yang mereka kembangkan masing-masing.

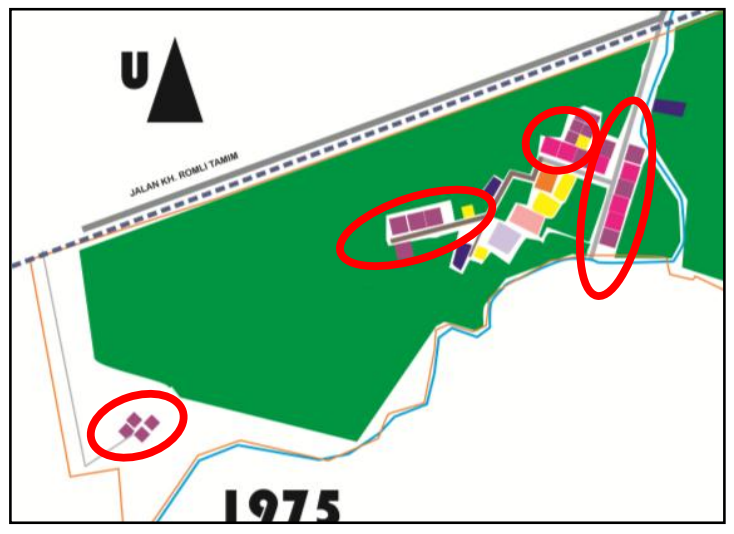

Gambar 13. Peta Lokasi Penelitian di Pesantren Darul 'Ulum Peterongan Jombang, 1975.

Seperti pada gambar 13. Perkembangan permukiman dari mulai pola permukiman linier, hingga sporadik, memusat, ada juga yang berkembang secara rural atau acak. Perkembangan permukiman ini membuat pola dari permukiman menjadi beranekaragam sesuai dengan kebutuhan mereka dan memanfaatkan sesuai dengan jaringan jalan. Masa kejayaan yang mengedepankan dari perkembangan infrastruktur dan jaringan jalan yang memadai untuk perkembangan dari pesantren dan kawasan permukiman itu sendiri.

\section{KESIMPULAN}

Pesantren Darul 'Ulum Peterongan Jombang adalah salah satu dari Pesantren yang ada di wilayah Jawa Timur. Yang mana sampai saat ini memiliki santri lebih dari empat ribu santri putra dan putri. Pesantren ini berlatar belakang dari kebutuhan wilayah asalnya yakni dikarenakan banyak permasalahan ekonomi, sosial kemasyarakatan dan pengetahuan keagamaan. Sehingga seorang ulama' yang berasal dari Madura bernama Kyai Irsyad Tamim mendirikan sebuah pesantren yang ada di tengah permukiman tersebut. Seiring berjalannya waktu pesantren dan wilayahnya ini mengalami perkembangan pesat, hingga pada masa kejayaannya yakni tepat setelah seabad berdirinya pesantren tersebut yakni pada tahun 1985 . 
Pada masa kejayaannya dipimpin oleh ulama' besar yang berkompeten memiliki kewibaan, kecerdasan dan keuletan dalam mengembangkan pesantren, beliau bernama Kyai Musta'in Romli yang masih keluarga dari Kyai Irsyad Tamim. Pada perkembangan masa kejayaan pesantren ini juga mengalami perkembangan pada kawasan permukimannya. Karena timbul rasa balas jasa dan kebaikan yang diajarkan dan ditularkan oleh pimpinan pondok baik secara kebudayaan, cara berfikir, kepercayaan, hubungan keluarga, organisasi sosial, hingga pada interaksi sosial. Membuat perkembangan penduduk dan permukiman menjadi semakin tinggi. Hubungan-hubungan inilah yang membuat perkembangan permukiman di pesantren Darul 'Ulum Peterongan Jombang menjadi lebih berkembang secara signifikan. Mulai dari perkembangan tempat tinggal, jaringan jalan, sarana, dan prasarana, hingga pada kebutuhankebutuhan fungsional lainnya termasuk dalam pemenuhan kebutuhan perekonomian masyarakat.

Pola dari persebaran permukiman yang ada pada permukiman sekitar pesantren Darul 'Ulum Peterongan Jombang adalah memiliki perkembangan permukiman yang bersifat tidak terencana dikarenakan berkembang sesuai dengan kebutuhan dan sesuai dengan adanya pergerakan fasilitas infrastruktur yang ada.

Pola perkembangan permukiman ada yang linier dan ada pula yang berkembang secara berkelompok baik pada bagian-bagian tertentu. Seperti pada wilayah yang jauh dari pusat kegiatan pesantren, mereka melanjutkan perkembangan permukiman secara tersebar atau sporadik. Pada perkembangan permukiman wilayah pesantren memiliki pola konsentrik yakni secara terpusat. Karena perkembangan permukimannya adalah memusat pada satu bangunan yakni Masjid utama pesantren Darul 'Ulum Peterongan Jombang.

\section{REFERENSI}

Armela, T. Et.al. (2015). Pengaruh Kondisi Permukiman Terhadap Preferensi Bermukim Buruh Industri Di Permukiman Tiban Kampung. Jurnal Dipublikasikan : AGORA, Jurnal Arsitektur, Vol. 15, No. 1, Juni 2015. Hal. 36-51. Universitas Trisakti.

Daldjoeni, N. (1998). Population : The Vital Revolution : Doubleday. New York

Depari, Catharina D.A. (2012). Transformasi Ruang Kampung Kauman Yogyakarta Sebagai Produk Sinkretisme Budaya. Jurnal Arsitektur KOMPOSISI, Vol. 10 No.01 Apil, 2012. Pogram Studi Arsitektur, Fakultas Teknik, Universtas Atma Jaya Yogyakarta.

Depari, C. Dwi Astuti dan Setiadi A. (2014). Makna Ruang Kampung Kauman Yogyakarta dan Semarang Berdasarkan Konsep Relasi Dalam Pandangan Jawa. Jurnal : Tata Loka Vol. 16 No. 3, Agustus 2014, hal. 133-144. ISSN : 0852-7458.

Herman, DM. (2013). Sejarah Pesantren di Indonesia. Jurnal Dipublikasikan : Jurnal Al-Ta'dib. Vol. 6 No. 2 Juli Desember 2013.

Moleong, J. Lexi. (2004). Metode Penelitian Kualitatif. Bandung : Remaja Karya.

Koentjaraningrat. 1983. Metode Penelitian Masyarakat. Jakarta : Gramedia Pustaka Utama.

Kostof, S. (1991). The City Shaped. London

Muhadjir, N. (1998). Metodologi penelitian kualitatif : pendekatan positivistik, rasionalistik, phenomenologik, dan realisme metaphisik telaah studi teks dan penelitian agama. Yogyakarta : Rake Sarasin.

Utaberta, N. (2007). Rekonstruksi Penguatan Pesantren dalam Pengembangan Civil Society di Era Globalisasi. Universiti Teknologi Malaysia.

Rapaport, A. (1970). The Study of Spatial Quality. The Urban International Pers.

Rapoport, A. (1969). House Form and Culture. New Jersey : Prentice-Hall. Englewood Cliffs.

Sonny Tilaar, Octavianus H.A Rogi, Alvin J. Tinangon. (2012). Kajian Morfologi Kawasan Permukiman Terencana di 
Kota Manado. Media Matrasain.

Volume 9, No.3:1-21

Sukamto. (1999). Kepemimpinan Kiai Dalam. Jakarta : LP3ES

Suprapti, A. (1997). Kajian Pola Spatial Kampung Kauman Semarang Sebagai Suatu Place. Tesis Magister Teknik Arsitektur UNDIP Semarang.

Utaberta, N. (2015). Green Architecture and Islamic Architecture : The Islamic Arabic City and the Traditional Islamic House. Journal Mechanic and Materials. Vol. 747, pp 24-27. ISSN : 1662-7482

Peraturan Kementrian Agama (KEMENAG) 2004.

Peraturan Daerah Kabupaten Jombang Nomor 21 Tahun 2009 tentang Rencana Tata Ruang Wilayah Kabupaten Jombang.

Dirjen Pendidikan Pondok (Ditpdpontren). Kementrian Agama (KEMENAG) Republik Indonesia.

US. Commission On International Religious Freedom ( USCRIF ) 2017 Annual Report. 